\title{
A case of pulmonary inflammatory myofibroblastic tumor treated with bronchoscopic therapy plus lobectomy
}

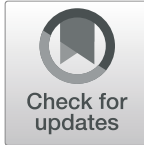

\author{
Fan Yang, Wenxia Zhang, Cheng Han and Hanliang Jiang * (D)
}

\begin{abstract}
Background: Inflammatory myofibroblastic tumor (IMT) is a rare tumor with malignant potential. We presented a case of a young adult who was diagnosed with IMT and treated with loop electrocautery therapy to relieve airway obstruction, followed by lobectomy to complete resection. Recent studies have supported the use of such interventional resection methods.
\end{abstract}

Case presentation: A non-smoking 30-year-old woman presented with a 1-month history of progressive dyspnea and productive cough. The Chest X-ray showed a homogenous opacity invading the entire left hemithorax, and the mediastinum content was attracted to the left side. In an effort to avoid pneumonectomy and afford rapid palliation of dyspnea, loop electrocautery was selected as the most appropriate therapy. The left upper lobectomy by thoracoscopy was performed instead of left upper lobe sleeve resection in order to better prevent the recurrence of lung atelectasis. After 6 years of follow-up, no evidence of recurrence has been found till now.

Conclusion: Interventional bronchoscopy coupled with surgical resection serves not only as a palliative management to bronchial obstruction but also a way to avoid pneumonectomy.

Keywords: Inflammatory myofibroblastic tumor, Lung neoplasm, Atelectasis, Interventional bronchoscopy, Surgery and oncology

\section{Introduction}

Inflammatory myofibroblastic tumor (IMT), first described by Brunn in 1939 [1], is a rare disease entity [2], also known as plasma cell granuloma or inflammatory pseudotumor. So far, it is still not clear whether these lesions are primary inflammatory processes or low-grade malignancies with obvious inflammatory reactions. Diagnosis of IMT is difficult to establish before surgery due to its diversified radiologic manifestations [3, 4], as the tumor can be cystic or homogeneous, parenchymal or endobronchial [5]. Complete surgical resection is a treatment option not only applied to exclude malignancy but

\footnotetext{
* Correspondence: aock@zju.edu.cn

Regional Medical Center for National Institute of Respiratory Diseases, Sir Run Run Shaw Hospital, School of Medicine, Zhejiang University, 3 Qingchun East Road, Jianggan District, Hangzhou 310016, China
}

also to achieve a good prognosis [6, 7]. In this report, we presented a case of IMT which was successfully removed by interventional bronchoscopy plus lobectomy [8].

\section{Case presentation}

A non-smoking 30-year-old woman presented with a 1month history of progressive dyspnea and productive cough. Her Chest X-ray showed a homogenous opacity invading the entire left hemithorax, and the mediastinum content was attracted to the left side. Hence, a diagnosis of left lung atelectasis was established (Fig. 1a). Bronchoscopy showed that the tumor completely obstructed the left main bronchus (Fig. 1c).

In an effort to avoid pneumonectomy and afford rapid palliation of dyspnea, loop electrocautery was selected as the most appropriate therapy. The lesion

C C The Author(s). 2021 Open Access This article is licensed under a Creative Commons Attribution 4.0 International License, which permits use, sharing, adaptation, distribution and reproduction in any medium or format, as long as you give appropriate credit to the original author(s) and the source, provide a link to the Creative Commons licence, and indicate if changes were made. The images or other third party material in this article are included in the article's Creative Commons licence, unless indicated otherwise in a credit line to the material. If material is not included in the article's Creative Commons licence and your intended use is not permitted by statutory regulation or exceeds the permitted use, you will need to obtain permission directly from the copyright holder. To view a copy of this licence, visit http://creativecommons.org/licenses/by/4.0/ The Creative Commons Public Domain Dedication waiver (http://creativecommons.org/publicdomain/zero/1.0/) applies to the data made available in this article, unless otherwise stated in a credit line to the data. 

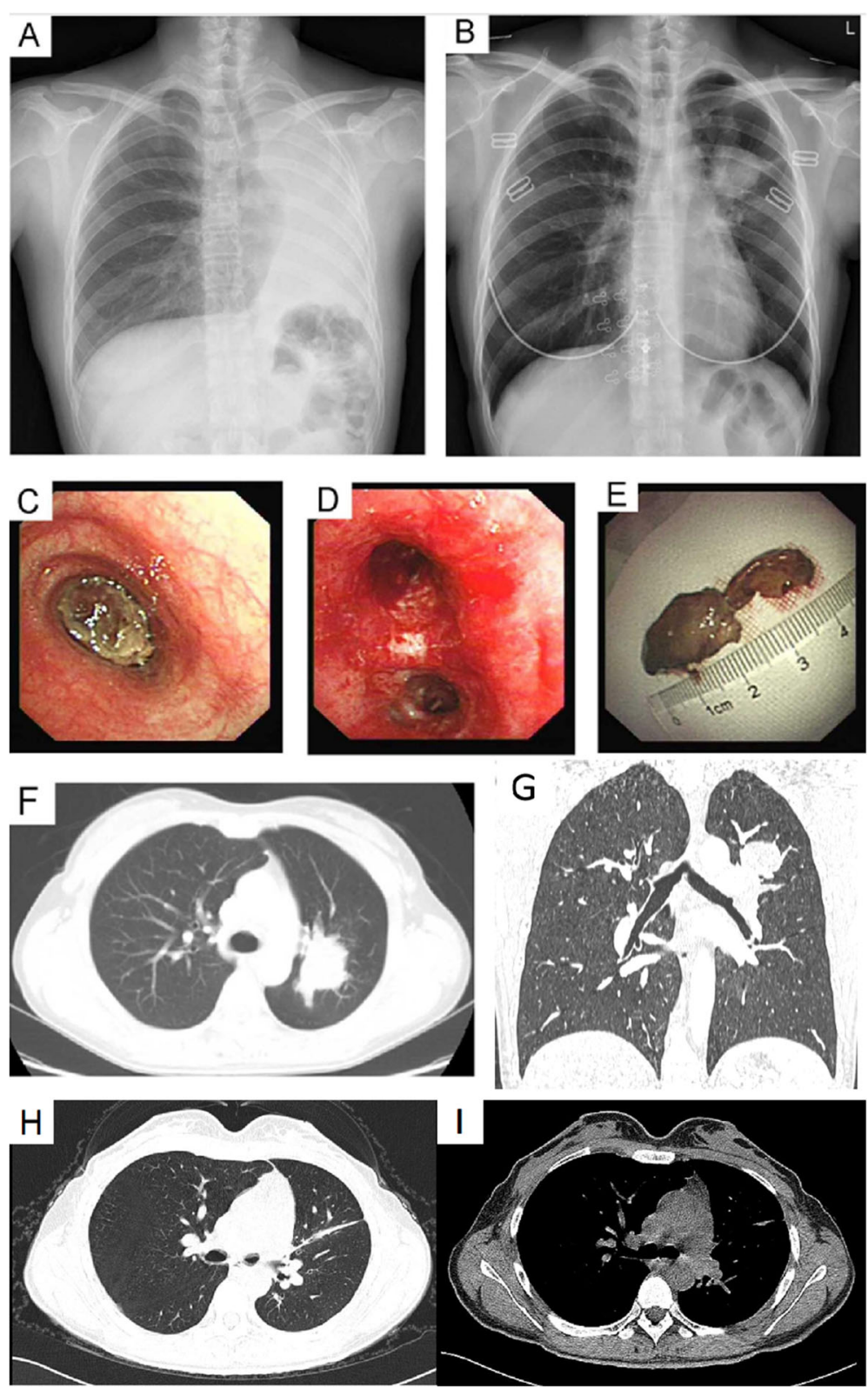

Fig. 1 Pulmonary mass. a: Left lung atelectasis was established by chest X-ray test. $\mathbf{b}$ : Chest X-ray showed a re-expansion of the left lung and a mass in the left upper lobe after interventional therapy. c: Bronchoscopy showed a tumor that completely obstructed the left main bronchus. $\mathbf{d}$ : The interventional therapy fully re-opened the obstructed left main bronchus and the lower subsegment of the left lower lobe. e: The lesion was partially resected by loop electrocautery via flexible bronchoscopy. f: Chest CT scan showed a tumor on the left upper lobe. $\mathbf{g}$ : Coronal CT after loop endoscopically resection on the left upper lobe. $\mathbf{h}$ : Chest CT scan showed the residual scar tissue after surgery a week later. $\mathbf{i}$ : CT demonstrated no relapse after a 6-year follow-up in 2019.12

was partially resected by loop electrocautery under the guidance of a flexible bronchoscopy [9]. Following resection, plenty of sputum was sprayed from the left lower lobe. This intervention completely re-opened the obstructed left main bronchus and the lower subsegment of the left lower lobe (Fig. 1d). Thereupon, the patient's dyspnea was resolved. Nevertheless, chest $\mathrm{X}$-ray showed a re-expansion of the left lung and a mass on the left upper lobe (Fig. 1b). After bronchoscopic procedure, the chest computed tomography (CT) scan showed a tumor on the left upper lobe (Fig. 1f and g).

Histologic examination of the lesion indicated inflammatory granulation tissue, the immunohistochemical (IHC) examination showed: CK (-); EMA (-); Vimentin $(+)$; SMA (+); Desmin (-); Calponin (-); ALK (-); S-100 
(-); CD34 (-); Ki67 (+); EBER (-), and thus the pathological diagnosis was IMT.

Thus, the surgery was resorted for diagnostic and therapeutic purposes after 45 days, consisting of a left upper lobectomy by thoracoscopy. We sent the specimen for frozen section and the pathological diagnosis was Inflammatory granulation tissue hyperplasia. Under gross examination, the tumor was $5 \mathrm{~cm}$ in size, and it was soft, jelly-like, homogeneous and invaded the bronchial wall locally. Besides, microscopic examination revealed proliferative regular spindle cells arrayed in fascicles, as well as admixed with lymphocytes, plasma cells and eosinophils (Fig. 2a, b and c). IHC examination revealed: Vimentin (+); SMA (+); CK (-); Myogenin (-); Desmin (-); S100 (-); CD117 (-); ALK (-) (Fig. 2d, e and $f$ ). No histologic evidence of metastasis to the lymph tissue was observed $(0 / 8)$ and the bronchial resection margin was negative. Only the residual scar tissue was found in CT after the surgery (Fig. 1h). Based on these data, the diagnosis of IMT was established. The patient was followed up every 3 months and received CT scan every 6 months. After 1 year of follow-up, no evidence of recurrence was found. The patient was lost to follow-up in the past 6 years until 8 months ago in 2019.12. Meanwhile the CT demonstrated no recurrence in the past 6 years (Fig. 1i).

\section{Discussion}

IMT is a rare pathologic entity, with its morbidity among patients with lung resection about 0.04\% [10]. IMT can occur in all age groups, but more than half of the patients are younger than 40 years old, meanwhile, it is indeed one of the most common primary lung tumors in the pediatric age group [11]. Most patients have respiratory symptoms, such as cough, dyspnea, fever, fatigue, and hemoptysis, whereas about $70 \%$ of patients have no symptoms [12]. Airway obstruction caused by IMT is rare [13]. The endobronchial and invasive parenchymal mass can easily cause pulmonary symptoms [14].

The radiologic features of IMT have been analyzed by Agrons [15] and the conclusion was that the radiological features are variable and non-specific. Infiltration of airways, calcification, and cavitation occur rarely. Most of the IMT is located peripherally and most of the time in the lower lobes. We presented a case of uncommon IMT which was in the central and affecting upper lobe, a similar report has been described before [16] coincidentally.

Diagnosis of IMT is dependent on surgical specimens. Because of the difficulty in distinguishing it from malignant tumors in small tissue samples that obtained from bronchoscopic examination, the diagnosis of IMT can also produce false positive and false negative results even with partially successful fine-needle aspiration biopsy [17]. Similarly, bronchoscopy can also hardly succeed as endobronchial IMT accounts for less than 5\% [18].

For patients who are not suitable for complete surgical resection, glucocorticoids, radiotherapy and chemotherapy can be supplied, yet both treatment success and treatment failure can be achieved [10]. In this report, we presented an extraordinary case where the patient won an opportunity for operation by receiving an interventional bronchoscopy treatment. It was essential and requisite to the patient as the tumor was found to be derived from the left upper lobe after loop electrocautery via flexible bronchoscopy. Therefore, the surgeon
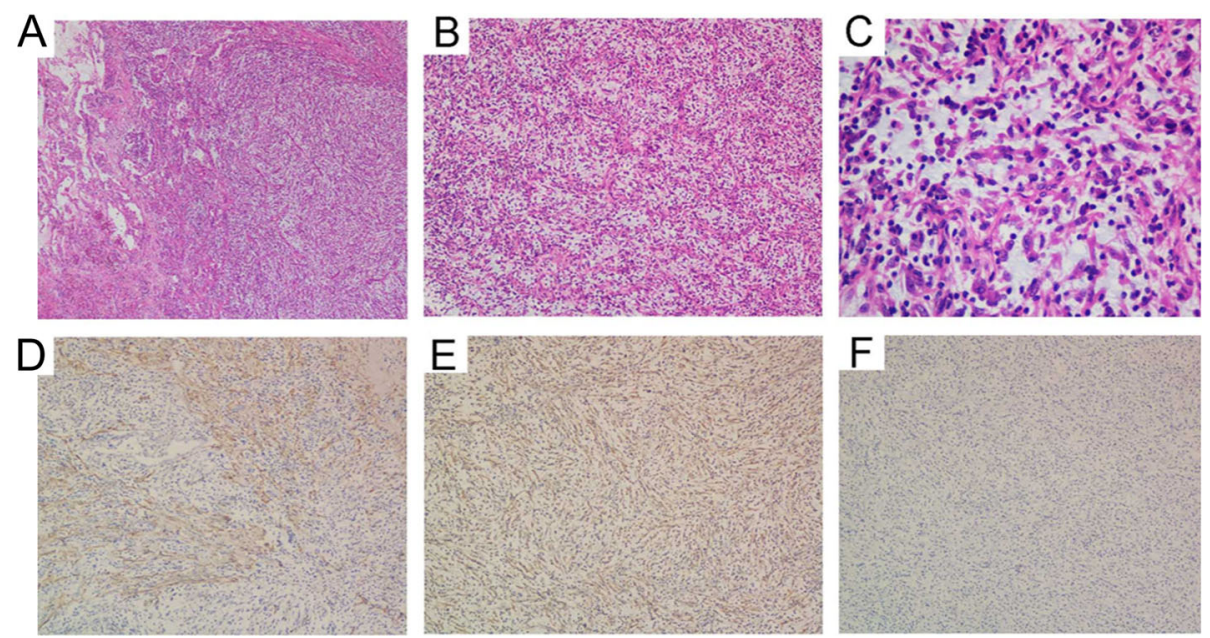

Fig. 2 Inflammatory myofibroblastic tumor. a: Low power view demonstrating intersecting fascicles of spindle cells in lung tissue associated with abundant vessels. b: Note abundant blood vessels in a myxoid stroma with loosened spindle cells, scattered lymphocytes and plasma cells. c: High power view showed spindle tumor cells with eosinophilic cytoplasm lack prominent nuclear atypia, though mitoses could be found. Tumour cells showed immunoreactivity for $\mathbf{d}$ : smooth muscle actin; e: Vimentin; and negativity for $\mathbf{f}$ : ALK 
adopted left upper lobectomy instead of left pneumonectomy. This approach not only served as a palliative management to bronchial obstruction, but also a way to avoid pneumonectomy [8]. Finally, the surgery performed was ordinary left upper lobectomy instead of left upper lobe sleeve resection in order to better prevent the recurrence of lung atelectasis. It is expected to be valuable for patients with similar medical conditions to undergo an interventional bronchoscopy before surgical resection.

The prognosis of patients undergoing complete resection of IMT is known to be with 5 -year and 10-year survival rate of 91 and 77\% [10]. The recurrence of IMT is rare, but it can be up to $60 \%$ in cases of incomplete resection [10] and the vast majority of deaths are secondary to distal metastases [19]. Finally, the surgery performed was ordinary left upper lobectomy instead of left upper lobe sleeve resection in order to better prevent the recurrence of lung atelectasis in this report. Postoperative pathology suggested that tumor infiltrating the bronchus could better prove this view. The patient was followedup regularly in the first year after the surgery and lost to follow-up in the past 6 years until 8 months ago. Fortunately, there was no evidence of relapse after the examination. Therefore, we proposed a follow up protocol for IMT: the CT should be received 3 months at the first 2 years after resection and extend to 6 months in the following 3 years. Annual follow-up should be finished in the last 5 years and the follow-up time should last for 10 years compulsively.

In all, IMT is rare, yet it should be considered as a differential diagnosis of pulmonary lesions. The prognosis of IMT is highly dependent on complete surgical resection. Besides, interventional bronchoscopy coupled with surgical resection can help avoid unnecessary pneumonectomy.

\section{Abbreviations}

IMT: Inflammatory myofibroblastic tumor; CT: Computed tomography; IHC: Immunohistochemical

\section{Acknowledgements}

Not applicable.

\section{Data sharing statement}

The data used to support the findings of this study are available from the corresponding author upon request.

\section{Authors' contributions}

FY and WX carried out most of the analyses. FY, WX, and XH drafted the manuscript. HL conceived and coordinated the study. All authors have read and approved the final manuscript.

\section{Funding}

This study was supported in part by grants from the Education of Zhejiang Province (Y201534623, Y201941509, Y201941229) and Zhejiang Provincial Natural Science Foundation of China (LY18H160007). The funders did not participate in the designing, performing or reporting in the current study.

\section{Availability of data and materials}

The data used to support the finding of this study are included within the article. The data and materials in the current study are available from the corresponding author on reasonable request.

\section{Declarations}

Ethics approval and consent to participate

Not applicable.

Consent for publication

All authors consent to submit the manuscript for publication.

\section{Competing interests}

The authors declare that they have no potential conflicts of interest.

Received: 3 February 2021 Accepted: 7 May 2021

Published online: 26 May 2021

\section{References}

1. Ochs K, Hoksch B, Frey U, Schmid RA. Inflammatory myofibroblastic tumour of the lung in a five-year-old girl. Interact Cardiovasc Thorac Surg. 2010; 10(5):805-6. PubMed PMID: 20139200. Epub 2010/02/09. eng. https://doi. org/10.1510/icvts.2009.219089.

2. Pettinato G, Manivel JC, De Rosa N, Dehner LP. Inflammatory myofibroblastic tumor (plasma cell granuloma). Clinicopathologic study of 20 cases with immunohistochemical and ultrastructural observations. Am J Clin Pathol. 1990;94(5):538-46. PubMed PMID: 2239820. Epub 1990/11/01. eng. https://doi.org/10.1093/ajcp/94.5.538.

3. Chen CK, Jan Cl, Tsai JS, Huang HC, Chen PR, Lin YS, et al. Inflammatory myofibroblastic tumor of the lung--a case report. J Cardiothorac Surg. 2010; 5(1):55. PubMed PMID: 20646317. Pubmed Central PMCID: 2915987. Epub 2010/07/22. eng. https://doi.org/10.1186/1749-8090-5-55.

4. Hammas N, Chbani L, Rami M, Boubbou M, Benmiloud S, Bouabdellah Y, et al. A rare tumor of the lung: inflammatory myofibroblastic tumor. Diagn Pathol. 2012;7(1):83. PubMed PMID: 22805416. Pubmed Central PMCID: 3482609. Epub 2012/07/19. eng. https://doi.org/10.1186/1746-1596-7-83.

5. Rasalkar DD, Chu WC, To KF, Cheng FW, Li CK. Radiological appearance of inflammatory myofibroblastic tumour. Pediatr Blood Cancer. 2010;54(7): 1029-31. PubMed PMID: 20127845. Epub 2010/02/04. eng. https://doi.org/1 $0.1002 / \mathrm{pbc} .22391$

6. Melloni G, Carretta A, Ciriaco P, Arrigoni G, Fieschi S, Rizzo N, et al. Inflammatory pseudotumor of the lung in adults. Ann Thorac Surg. 2005; 79(2):426-32. PubMed PMID: 15680808. Epub 2005/02/01. eng. https://doi. org/10.1016/j.athoracsur.2004.07.077.

7. Sakurai H, Hasegawa T, Watanabe S, Suzuki K, Asamura H, Tsuchiya R. Inflammatory myofibroblastic tumor of the lung. Eur J Cardiothorac Surg. 2004;25(2):155-9. PubMed PMID: 14747105. Epub 2004/01/30. eng. https:// doi.org/10.1016/S1010-7940(03)00678-X.

8. Porpodis K, Karanikas M, Zarogoulidis P, Kontakiotis T, Mitrakas A, Esebidis A, et al. A case of typical pulmonary carcinoid tumor treated with bronchoscopic therapy followed by lobectomy. J Multidiscip Healthc. 2012; 5:47-51. PubMed PMID: 22396625. Pubmed Central PMCID: 3292401. Epub 2012/03/08. eng. https://doi.org/10.2147/JMDH.S29709.

9. Panagiotou M, Kalkanis A, Karagiannidis N, Polychronopoulos V. A case of tracheal hamartoma resected with loop electrocautery. Case Rep Pulmonol. 2013;2013:568590 PubMed PMID: 23401830. Pubmed Central PMCID: 3557623. Epub 2013/02/13. eng.

10. Cerfolio RJ, Allen MS, Nascimento AG, Deschamps C, Trastek VF, Miller DL, et al. Inflammatory pseudotumors of the lung. Ann Thorac Surg. 1999;67(4): 933-6. PubMed PMID: 10320231. Epub 1999/05/13. eng. https://doi.org/10.1 016/50003-4975(99)00155-1.

11. Lai $L M, M c C a r v i l l e ~ M B$, Kirby $P$, et al. Shedding light on inflammatory pseudotumor in children: spotlight on inflammatory myofibroblastic tumor. Pediatr Radiol. 2015;45(12):1738-52. https://doi.org/10.1007/s00247-015-33 60-6.

12. Berardi RS, Lee SS, Chen HP, Stines GJ. Inflammatory pseudotumors of the lung. Surg Gynecol Obstet. 1983;156:89.

13. Lee HJ, Kim JS, Choi YS, Kim K, Shim YM, Han J, et al. Treatment of inflammatory myofibroblastic tumor of the chest: the extent of resection. 
Ann Thorac Surg. 2007;84(1):221-4. PubMed PMID: 17588417. Epub 2007/ 06/26. eng. https://doi.org/10.1016/j.athoracsur.2007.03.037.

14. Andrade FM, Abou-Mourad OM, Judice LF, Carvalho-Filho AB, Schau B,

Carvalho AC. Endotracheal inflammatory pseudotumor: the role of

interventional bronchoscopy. Ann Thorac Surg. 2010;90(3):e36-7. https://doi. org/10.1016/j.athoracsur.2010.06.013.

15. Agrons GA, Rosado-de-Christenson ML, Kirejczyk WM, Conran RM, Stocker JT. Pulmonary inflammatory pseudotumour: radiologic features. Radiology. 1998;206(2):511-8. https://doi.org/10.1148/radiology.206.2.9457206.

16. Gulbanu HE, Osman H. Ay Ccedil, et al. inflammatory Myofibroblastic tumor of the lung. J Coll Physicians Surg Pak. 2016;26(4):331-3.

17. Urschel JD, Horan TA, Unruh HW. Plasma cell granuloma of the lung. J Thorac Cardiovasc Surg. 1992;104(4):870-5. https://doi.org/10.1016/S00225223(19)34664-1.

18. Thistlethwaite PA, Renner J, Duhamel D, Makani S, Lin GY, Jamieson SW et al. Surgical management of endobronchial inflammatory myofibroblastic tumors. Ann Thorac Surg. 2011;91(2):367-72. https://doi.org/10.1016/j.athora csur.2010.09.017

19. Kato $\mathrm{S}$, Kondo K, Teramoto T. A case report of inflammatory pseudotumour of the lung: rapid recurrence appearing as multiple lung nodules. Ann Thorac Cardiovasc Surg. 2002;18:541-4.

\section{Publisher's Note}

Springer Nature remains neutral with regard to jurisdictional claims in published maps and institutional affiliations.

Ready to submit your research? Choose BMC and benefit from:

- fast, convenient online submission

- thorough peer review by experienced researchers in your field

- rapid publication on acceptance

- support for research data, including large and complex data types

- gold Open Access which fosters wider collaboration and increased citations

- maximum visibility for your research: over $100 \mathrm{M}$ website views per year

At BMC, research is always in progress.

Learn more biomedcentral.com/submissions 